\title{
IJELTAL
}

\section{The Online Media Practice in Covering Indonesian National Police's Prevention Efforts on the Prohibited Party's Ideology Spread in Indonesia}

\author{
Intan Mustika Sari \\ Universitas Sebelas Maret \\ e-mail:intanmustikasari65@gmail.com
}

\begin{abstract}
:
Critical discourse analysis examines the efforts of social forces and ideological interests of a group that are reproduced and defended through texts. The discussion is connected with social contexts that have specific purposes and assumptions. This study focuses on online news reported at liputan6.com site on May 11 th, 2016. This study's method is a critical discourse analysis introduced by Norman Fairclough with the implementation of transitivity system as the data analysis theory. It aims to uncover the elements of social practice from the aspects of linguistic and discourse. The result indicates the existence of social practice from the online news site in processing information shapes the practice representation conducted by figures who act the discourse which can affect the views of people including their understanding and behavior in social life.
\end{abstract}

Keywords: critical discourse analysis, social practice, transitivity

\section{Introduction}

Mass media have various functions. One of them is a tool for political control of society that can provide various information about social deviation committed by a certain social institution such as the government, a private sector, or a community (Gurevitch \& Blumler, 1990). According to Fairclough, the act of mass media coverage such as journalism belongs to social practices that are civic in nature (Fairclough, 1992). 
Mass media can be considered as a form of discourse which has a function as a very effective mean of social practice of forming public opinion, especially in the form of online newspapers. This is due to technological advances that enable forms of discourse in cyberspace to circulate information more quickly in the community. In this discourse, the online news site uncovers the Indonesian Nasional Police actions in preventing the spreading of ideology carried out by a prohibited party in Indonesia.

Several previous studies have been conducted to examine this kind of social practice. However, they were carried out with different methods or towards different research objects. Wahyudin (Wahyudin, 2019) analyzed news item which only focuses on the process type of the text by using transitivity to identify a certain process type of the text which can influence the readers. He found that the verbal process dominancy in the article indicates the effectiveness of news items in persuading Indonesian people agreement with nuclear power plants. The second transitivity study was conducted by Pradnyadari, Aryawibawa, and Rahayuni who looked for the type of transitive verb which was found in a storybook of Disney Storyland Treasury entitled "Pinocchio". The results show that there were three types of verbs referring to process verb, action verb, and state verb (Pradnyadari et al., 2018). Cunanan conducted a study using a transitivity system to analyze fiction styles which are according to lexico-syntactic features, strategies in presenting perspectives of characteristics, and also categorization of the choices in combining words. One of the results is the students' EFL or ESL can obtain a deeper appreciation of the worldview and the perspective according to the author and his characters (Cunanan, 2019).

On the other side, Putra and Triyono carried out a study by using critical discourse analysis toward the news entitled Gerakan 2019GantiPresiden di Antara Ambiguitas Hukum dan Syahwat Politik at Kompas.com. However, he only found out the linguistic aspects of diction in the form of direct sentences utilized by the site based on the micro, mezzo, and macrostructural analysis that showed the constitutional movement of a rebellion supported by the rival political interest (Putra \& Triyono, 2018). Meanwhile, Sahmeni and Afifah (Sahmeni \& Afifah, 2019) conducted a study on how to unravels the covert ideologies through CDA proposed by Van Djik in media discourse studies. This study uncovers the important role of media in the production of trust, dominance, and prejudice over the analyzed social contexts without analyzing the linguistic elements of the sentence. Those previous studies confirm that transitivity can be used to uncover power relations by analyzing the participants' roles in each process employed in the text, and the study critical discourses analysis is essential for uncovering thoroughly about the power relation and the social representation contained in the text. Tewarat and Triyono studies the self-image of President Joko Widodo in the International Speech at the World Economic ASEAN 2018 through the analysis approach of critical linguistic developed by Fowler (1979). The result indicates the purpose of President Joko Widodo in elaborative phrase in the speech context (Tewarat \& Triyono, 2019).

In addition, Bustam conducted a research which has a purpose to obtain a clear description from the process of transitivity system that as the method for analyzing clause according to ideational function of language. He found that transitivity analysis can be exercised to discover personal reference of potential ambiguity (Muhammad Rayhan Bustam, 2011). Anggraini used transitivity system to conduct a research for investigating the transitivity process which unveils ideological construction and linguistic strategies of Donald Trump 
used in his speech in the 45th United States presidential election. She discovers 708 clauses contain transitivity process used as persuasive strategy to convince the public (Anggraini, 2018). Mustika and Mardikantoro implemented critical discourse analysis introduced by Norman Fairclough for describing the discourse textual level on the corruption news reported by Trans TV and Global TV media. The result shows that E-KTP corruption news was broadcasted on Trans TV in the form of a formal vocabulary with active and passive sentences besides applying euphemism, while Global TV used informal vocabulary and metaphors in the structure of news elements (Mustika \& Mardikantoro, 2018). Shi and Fan conducted a study which aims to find out different ideologies in news report entitled "the Belt and Road" (B\&R) in Chinese and American media, then confirms the function of transitivity system. The result found that news report cannot be considered transparent and also impartial that reflects objective facts since it was used to deliver the government interests and social ideologies (Shi \& Fan, 2019). Asad et al. used Transitivity Analysis introduced by Halliday from edited work of Matthiessen. She found out that the newspapers of 'Malaysiakini' and 'Dawn' in Malaysia and Pakistan more neutral in reporting by giving fair representation to social actors. On the other hand, 'The New Straits Times' delivered corruption matters after elections in Malaysia, while 'The News' in Pakistan has shown his inclination towards the existing facts in the 2018 elections. They applied direct source in delivering news to influence the reader about corruption as sensitive issue in both country around the elections (Asad et al., 2019). Based on this consideration, this study applies transitivity system which was embedded in an analytical discourse analysis in Fairclough's framework.

Based on the consideration of the previous studies, this study has more concern to discover the dominating practice carried out by a certain party to the powerless one in not only based on the language tools utilized in the text, but also according to the specific context exists in the text production of online news as well as the from the viewpoint of speech act analysis that represents the sayer's intention and the potential effect on the audience. Furthermore, the different object of study becomes the novelty of this research This study has a purpose to reveal the online news article's way in representing the values of a certain ideology found in an online news article in the frame of critical discourse analysis introduced by Fairclough combined with transitivity as the data analysis theory. In this case, the linguistic analysis used in the online news text is needed to have a proper understanding of critical discourse analysis. The research problems that will be answered in this study include (a) how the online news represents the social actors and their practices through language tools, and (c) how the practice of reporting in the online news site affects the cognition of the reading community.

\section{Literature Review}

\subsection{Critical Discourse Analysis}

Critical Discourse Analysis (CDA) is a kind of analysis which seeks the relationship between language and ideology (Orpin, 2005). It brings a concept of news values through the analysis constructed values' systematic on how the events are systematically constructed (Bednarek \& Caple, 2012). In this consideration, language plays an important role in the communication process. It can be seen from the linguistic system of the text that represent the context of culture and the situation (M. Halliday et al., 2014). The context refers to how 
the discourse is produced, understood, and then interpreted in certain ways. It is like who communicates with whom, why the communication is occurred, what kind of community is like, what the situation is, through what facility is, how the communication is developed, and how the relationships among participants are (Eriyanto, 2001). The texts as discourse can be regarded as social places that becomes representation of the world as a product of social interaction processes that occur simultaneously. There are three phases of text. The first phase is started when the text is affected by social-cultural practice that lead into production process and the interpretation occurs. This relationship is well known as dialectical among discourses that possibly connects language with ideology (Wodak, 2006).

In Fairclough's framework, critical discourse analysis consists of three stages. They are description, interpretation, and explanation. This kind of analysis considers the discourse as a part of social process and practice (Fairclough, 2000). Furthermore, Eriyanto states critical discourse analysis contain five principles, including action, context, history, power, and ideology. Therefore, discourse is regarded as a mean of social practices which can be used to influence, react refute, debate, persuade others, and it is expressed and controlled consciously by a certain group (Eriyanto, 2001). Critical discourse analysis comes as an effort or a process of text decomposition to explain a text as a form of social reality that is exercised by someone or institution that has a specific interest to reach the goal. This kind of analysis has been implemented widely to criticize and discover the relationship between language and practice of social and political issue (Yoce, 2009).

\subsection{The Practice of Mass Media}

In the practice of power, mass media become part of a ruling party's mechanism to maintain its position through the information that is disclosed in the media (Carey, 1965). Media are seen as the agents of social constructions that define reality according to their interests, and they become the manifestation of ideological struggles among groups in society. In carrying out the practice, media are influenced by social structures such as religious structures, social class structures, and social value structures, including the language structure of community groups used to carry out the practice of reporting in the media. Therefore, social relations, ideological values, and other forms of community belief will determine the content of news in the media. From the perspective of critical discourse analysis, there is a relationship between micro and macro contexts in the social structure where the language is used in the practice of power (Fairclough, 2003).

It can be interpreted that a certain dominance or hegemony practice uses discourse as a tactical element to influence the people's mindset. Hegemony becomes a special type of power relation which is often manifested in the legitimacy of ideologies or views held by dominant groups to form new political ethics (Gramsci \& Hoare, 1971). In the case of power relations, Watson states that there is an unequal distribution of power in the social practice which can influence people's ways of thinking. It is related to the socialized norm which is constructed as guidelines in their actions (Watson, 2017). Prayitno et al. also found out that there is a relationship between power and a socialized norm such as politeness toward those who have higher social in the hierarchal social relation of that community. Moreover, it should be maintained by using language (Prayitno et al., 2018). Thus, this is all related to the development of domination and it can be regarded as the preservation of power for the social leader. 
Public arguments can be shaped simultaneously and uniformly by the ideological struggles among powerful groups that use media content to influence the processes of readers or audience reception in negotiating their beliefs and attitudes as the response to media messages. Eriyanto considers that media are not free and neutral channels, but are owned by certain groups and used to dominate groups that are not dominant (Eriyanto, 2001). Mass media can be considered as a form of discourse which has a function as a very effective mean of forming public opinion, especially in the form of online newspapers. This is due to technological advances that enable forms of discourse in cyberspace to circulate information more quickly in the community.

\section{Research Methodology}

\subsection{Data and the Source of Data}

This study used a qualitative approach to process data empirically that applied the researchers' comprehension of the interactions among particular concepts that were being investigated for understanding the phenomena experienced by the research subjects (Rinaldi, 2017). The data source was online news retrieved from http://news.liputan6.com. The news was reported by Luqman Rimadi on May $11^{\text {th }}, 2016$. The data were in the form of clauses and lexicons with the keywords "Badrodin Haiti" used to represent Polri as a part of government institutions. In this study, the figure "Badrodin Haiti" acted as the actor or the sayer, and "the prohibited party" acted as the token. The data were analyzed using a critical discourse analysis approach according to Fairclough's perspective to show the practice of media in covering the actions of Polri against the suspected sympathizers of prohibited party in Indonesia.

\subsection{Instruments}

Transitivity was applied as the data analysis theory to describe the experience based on reality as a type of process associated with participants and circumferences (Halliday \& Matthiessen, 1985). Transitivity was conducted by selecting the types of process and the participant's role in the event described in the text. This study applied a referential method. This method is useful to define the lingual unit identity of each determinant. The intended determinants refer to the objects, events, facts, attributes, relations or everything (out-oflanguage) which were designated by language as the informational content of what being communicated on the text (Sudaryanto, 2015). All the data taken from the resources were collected into this following table to see the whole realization in verbs stated in the online news.

Table 1 Realization of Processes in Verbs Practiced by Polri in the Online News

\begin{tabular}{|ll|}
\hline \multicolumn{1}{|c|}{ Process Types } & Realization in Verbs (plus Nouns) \\
\hline Material Process (and the targets) & $\ldots$ \\
\hline Mental Process (and the phenomenon) & $\ldots$ \\
\hline Verbal Process & $\ldots$ \\
\hline Relational Process (and the attributes) & $\ldots$ \\
\hline Behavioral Process & $\ldots$ \\
\hline
\end{tabular}


The further step is analyzing data in more details according to the types of process and presented in this kind of following table.

Table 2 Material Process

\begin{tabular}{|ccccc|}
\hline Material Process & $\begin{array}{c}\text { Participant: } \\
\text { Actor }\end{array}$ & Material & Goal & Circle \\
\cline { 2 - 5 } & $\ldots$ & $\ldots$ & $\ldots$ & $\ldots$ \\
\hline English Gloss & $\ldots$ & $\ldots$ & $\ldots$ & $\ldots$ \\
\hline \hline
\end{tabular}

In analyzing data, the method of data reduction was also used to reduce some elements in the sentence. Miles stated that data reduction is the process of focusing, selecting, and simplifying the complex data (Miles \& Huberman, 1984). It is useful to see the causality of structural changes after removing one or some elements. By removing a certain element, the core level of the omitted elements can be investigated. The reduction process was conducted by knowing first the core level of the omitted elements in the sentences, therefore the mistake of omitting some elements of the sentence can be prevented since the element with high core level will not be eliminated.

\subsection{Data Analysis Procedures}

The data analysis was carried out through three stages: (1) describing the news text, (2) interpreting the relationship between the news text and the production process in the text, and (3) explaining the effect of the online media in reporting the event on the reading community cognition (Fairclough, 2000). The concept of explanation with the implications, presuppositions and general assumptions of the Indonesian people as the readers were also used to explain the relationship between the discourse process and the social context in the online news reporting, and also the social impact of forming the public opinion that can occur as the result of media practices in discourse. The concepts of ideology, hegemony, and dominance applied by a powerful group against the others were also used to see the social context that played a role in the process of discourse.

\section{Findings and Discussion}

\subsection{Transitivity to Reveal the Indonesian Nasional Police Actions}

The way of the news article in portraying the action of Indonesian Nasional Police towards the movement to spread a prohibited ideology in Indonesia can be analyzed by implementing a transitivity system. The data categories used in this study are the spoken utterances said by the actor/ sayer who mostly refers to Badrodin Haiti as the representatives of Polri (Indonesian Police) institution in dealing with the spread of prohibited ideology symbols issue in Indonesia based on the applied positive laws in Indonesia. The data analysis result indicates the action by Polri and TNI (Indonesian National Armed Forces) as the groups that enforces Indonesian laws towards the prohibited groups who are considered to have a forbidden ideology in Indonesia.

The actions carried out by the Indonesian Nasional Police were mentioned in five types of processes with a various number of percentages that can be seen based on the realization in verbs. The following data are the police actions reported by the online news site. They were categorized according to the process types realization in various verbs (plus nouns). 
Table 3 Realization of Processes in Verbs Practiced by Polri in the Online News based on Transitivity System (Halliday and Matthiessen, 1985)

\begin{tabular}{|ll|}
\hline \multicolumn{1}{|c|}{ Process Types } & \multicolumn{1}{c|}{ Realization in Verbs (plus Nouns) } \\
\hline Material Process (and & $\begin{array}{l}\text { menyisir lokasi perbelanjaan Blok M Square dan Blok M Mall; menyita barang } \\
\text { bukti; menegakkan aturan; melibatkan jajaran di Kejaksaan dan juga TNI; } \\
\text { lakukan langkah hukum; gunakan pendekat hukum } \\
\text { (searched for locations of Blok M Square and Blok M Mall; confiscated } \\
\text { evidences; enforced rules; involved the ranks of Attorneys and also TNI; took } \\
\text { the legal steps; used the legal approach) }\end{array}$ \\
\hline Mental Process & $\begin{array}{l}\text { menduga } \\
\text { (suspected) }\end{array}$ \\
\hline Verbal Process & $\begin{array}{l}\text { menegaskan, imbuh, mengatakan, ujar } \\
\text { (emphasized, added, stated, said) }\end{array}$ \\
\hline $\begin{array}{l}\text { Relational Process } \\
\text { (and the attributes) }\end{array}$ & $\begin{array}{l}\text { yang berkaitan dengan penegakan hukum ini } \\
\text { (related to this law enforcement) }\end{array}$ \\
\hline Behavioral Process & $\begin{array}{l}\text { tanggung jawab untukfollow up } \\
\text { (responsibility for following up) }\end{array}$ \\
\hline
\end{tabular}

The total percentage of these process types used in the news article can be realized in the form of a pie chart in Figure 1.
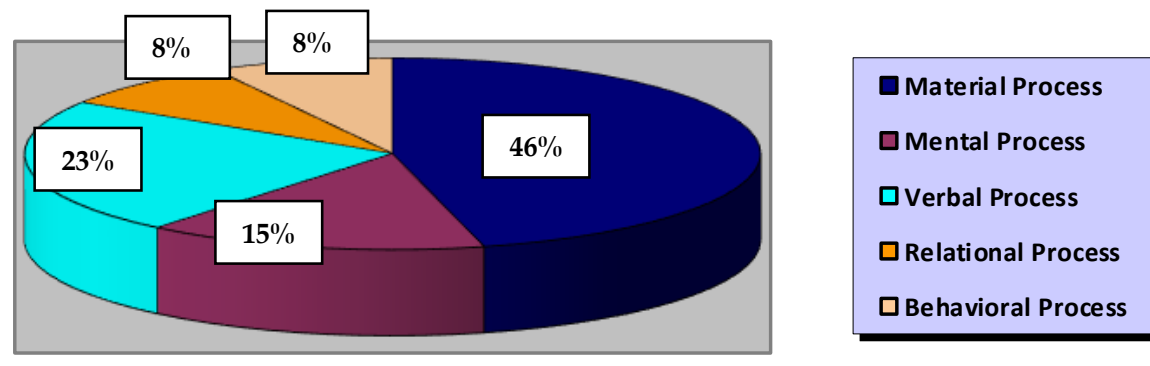

Figure 1. Percentage Use of Processes in the Online News

From the calculation of several process types used in the text according to transitivity theory, it can be seen that the dominant process was used to describe the actions of the Indonesian Nasional Police in cooperating with TNI to prevent the spread of prohibited party symbols is a material process with the percentage of $46 \%$, then followed by a verbal process of $23 \%$, and mental process of $15 \%$. The relational and behavioral processes are only once in the text, so they have a very low percentage which is only $8 \%$ of the overall use of processes. As such, these two types of processes are not counted as strong references to see the practice of domination by the Indonesian Nasional Police on the suspected prohibited party sympathizers in this online news article. 
The domination of the material process showed in Table 4 which almost reaches half of the total number of processes in the online news article in reporting the event shows the emphasis of power usage exercised by the police clearly because it is carried out in real action which had the strongest impact on preventing the spread of the forbidden party ideology compared to the use of other types of processes aimed at Indonesian society. This type exposes the manifestation of the Indonesian national polices' real action, their seriousness and absolute certainty in carrying out the state duties in order to maintain the only one ideology of Pancasila that is allowed under positive laws in Indonesia as the guideline for having the national life in Indonesia. The characterization of Haiti as a part of the Indonesian Nasional Police institution who has the authority to uphold Indonesian regulations was also illustrated through the circumference in the transitivity system. Generally, this online news used a circumstance which could give the readers information about the setting of place and time and it is applied to provide information about how the police carried out their mandate in their duties.

This collection of data on all realizations of the processes types in verbs used in conveying the news on Indonesian national police actions against the suspected sympathizers of the forbidden party can provide clearer result compared to the research conducted by Shi and Fan (2019) in knowing which form of the verbs is the most significant which was outlined in the various processes composing the news in the framework of forming public opinion through the use of language in the news text. Shi and Fan saw and examined the entire types of processes contained in the news reports on "the Belt and Road" (B\&R) separately instead of providing the overall interpretation of using linguistic tools as a whole concept of social practice in the aim in the case for exploring the different ideologies conveyed by the news reports.

Table 4 Material process analysis of datum 1

\begin{tabular}{|lllll|}
\hline Material Process & \multicolumn{1}{c}{$\begin{array}{c}\text { Participant: } \\
\text { Actor }\end{array}$} & \multicolumn{1}{c|}{ Material } & Goal & \multicolumn{2}{c|}{ Circle } \\
\cline { 2 - 5 } & Polri & gandeng & TNI & cegah penyebaran simbol. \\
\hline \hline English Gloss & Polri & $\begin{array}{l}\text { collaborated } \\
\text { with }\end{array}$ & TNI & $\begin{array}{l}\text { in preventing the spread of } \\
\text { symbols. }\end{array}$ \\
\hline
\end{tabular}

Written as the news title showed in Table 4, Polri was described as a party that has the ability to gain power and authority in dealing with other parties that are likely to violate legal laws in Indonesia. This action was further strengthened by the effort to collaborate with another party who at least has equal power in exercising law enforcement to take action against the group deemed opposes the legal laws and regulations applied in Indonesia. Besides, the choice of the word "collaborated" (menggandeng) can also reflect the effort of the news to expose to the public that Polri and TNI have the same position as institutions with legal force in charge of maintaining the national security and stability, both of which will be able to join hands for supporting each other to achieve the same goal, it is to prevent the spread of the prohibited party's ideology in Indonesia. In addition, the online news uses the term "prevented" (mencegah) to shape the mindset of the community that the ideology carried by the prohibited party is a bad and wrong thing that should not be allowed to develop further in Indonesia that embraces the ideology of Pancasila. Therefore, the symbols or attributes which represent the view of prohibited party must be confiscated. 
This kind of representation is shown by Mardikantoro in the matter of corruption which were manifested in the editorial discourse of (anti) corruption through this views and attitudes newspaper. With a frame of anti-corruption supporting, the media agreed on the views and attitudes then implicitly support the efforts to eliminate corruption which can be that were realized in the action of arresting the suspected corruptors according to legal verdicts (Mardikantoro, 2014). It has the same practice conducted by liputan6.com online media to cover the action of Polri in eradicating the forbidden ideology whose presence against legal rules in Indonesia.

In expressing his opinion, Haiti was also described as doing a verbal process (Table 5). Among those verbs which are used to realize the verbal process, the verb "emphasized" (menegaskan), "added" (imbuh), "stated" (mengatakan), and said (ujar) show the behavior of Haiti as a party that has dominance to speak about the case.

Table 5 Verbal process analysis on datum 2

\begin{tabular}{|c|c|c|c|c|}
\hline & Sayer & Process & Senser & Circle \\
\hline $\begin{array}{l}\text { Verbal } \\
\text { Process }\end{array}$ & $\begin{array}{l}\text { Jenderal Polisi } \\
\text { Badrodin Haiti }\end{array}$ & menegaskan & $\begin{array}{l}\text { keberadaan kaus atau berbagai } \\
\text { atribut bergambar ... }\end{array}$ & $\begin{array}{l}\text { merupakan suatu } \\
\text { bentuk pelanggaran } \\
\text { hukum. }\end{array}$ \\
\hline $\begin{array}{l}\text { English } \\
\text { Gloss }\end{array}$ & $\begin{array}{l}\text { The Police General } \\
\text { Badrodin Haiti }\end{array}$ & emphasized & $\begin{array}{l}\text { the existence of } t \text {-shirts or } \\
\text { various attributes with the } \\
\text { pictures of ... }\end{array}$ & $\begin{array}{l}\text { is a form of } \\
\text { violation of the law. }\end{array}$ \\
\hline
\end{tabular}

The online news' way in portraying the character of Haiti who acted verbally using the verb choice "emphasized" reflects the intention of the news site in bringing up the figure of Haiti as a party that has the power, so that it was manifested in a choice of verbs that gives more emphasis than just "said" for the reader's cognition that what he said about the form of violation of Indonesian law is a fact or a truth that really must be put in the readers' mind. In shaping public's opinion, the online news article was used as a media for delivering hidden intention of major group to control public attitude and behavior as Indonesia people to be always obey the laws upheld by Indonesian government. This practice has the same idea with the statement delivered by Eriyanto that discourse uses language as a tool to conduct social practice. Therefore this action is not just an individual's activity, but it reflects on something contained on the text (Eriyanto, 2001).

There are two statements of Haiti in this news than can be analyzed further, include (1) "Symbols that refer to the prohibited party through t-shirts and attributes must be prevented immediately", and (2) "We use the legal approach". It can be seen that speech (1) is a state of affirmation about the authority of the chief of Indonesian national police regarding the incident that has unsettled Indonesian people. The word "must (harus)" in the speech indicate an emphasis to show partiality to the government that has the highest authority in Indonesia, meanwhile, speech (2) is one of the verbal acts of the declaration carried out by Haiti which reflects the absence of slightest doubts about what he said, and with the lack of modality he used in his speech, he seemed to have a high commitment in launching his power practice. This practice of power was demonstrated by the sayer who represent the police action in using legal enforcement to crack down the spread of 
prohibited party's ideology. This action points out the special power of Polri and TNI in upholding authentic laws in Indonesia.

The discourse in this online news illustrated the power relations which led to the same thing, regarding who was in power and who was prohibited in media rhetoric through the language tools. In this case, the model is declarative which shows that there were two opposing groups, namely the Indonesian government which was represented by Indonesian national police (described as the actor), and the suspected sympathizers of the prohibited party (described as the token). The online news site of liputan6.com shaped particular opinions in Indonesian society using the term of prohibited party mentioned in the online news for referring to the figures behind the movement in spreading the ideology of prohibited party. It was conducted to construct shared knowledge in the community that the prohibited party is such kind of separate group, and it opposes to other members of the community including readers who do not share the same ideology as to the group. The act of emphasis as the verbal process indicates the implementation of power by dominant group in creating social structures in community which are in lines with its interest. Adje states that the world can be represented in an unlimited number of ways in which context and culture becomes essential in the discursive interactions among the members of society (Adjei, 2013). In this way, the social context and culture which contain some ideology and other special interest reconstruct interactions in the community which gives a rise a certain discourse as a product of social interaction. The use of language unit existing in the context here carries out a certain social function, that is to influence other people to agree what the sayer said.

In describing the targeted activities, this online news portrayed Indonesian Nasional Police as a figure in carrying out the action of a strict oppressive movement towards the prohibited organization according to the procedures that have been established by law in Indonesia. This eventually formed the public opinion that prohibited party was an organization that committed a major crime and it was considered dangerous so that this ideology existence was prohibited in Indonesia. Physical activity such as "searched for" (menyisir); "confiscated" (menyita); "upheld" (menegakkan); and "involved" (melibatkan)" show the manifestation of the police force which seeks to secure the alleged attributes as a way of spreading prohibited party's ideology.

The polices are also depicted in taking actions that use cognition, as illustrated in Table 6:

Table 6 Mental process analysis of datum 3

\begin{tabular}{|llll|}
\hline Mental Process & \multicolumn{2}{c}{ Mental: Cognitive } & Phenomenon \\
\cline { 2 - 4 } & $\begin{array}{l}\text { (Terdua simpatisan } \\
\text { partai terlarang) }\end{array}$ & diduga & menyebarkan \\
\hline \hline English Gloss & $\begin{array}{l}\text { (The suspected } \\
\text { sympathizers of } \\
\end{array}$ & was suspected & spread \\
& & & \\
\hline
\end{tabular}

The word "suspected" (menduga) used by Haiti for looking at the phenomenon reflects his prudence under the Indonesian legal principle "presumption of innocence". It is the principle under which a person is not stated guilty until the authorized court judges guilty. Haiti used the term "suspected" to show the indirect nature of judging that activities of distributing 
merchandise are related to the dissemination of the prohibited party's ideology. This mental process can be used to represent the positive behavior of Indonesian national police in carrying out the matters that oppose to the state regulations. In CDA, discourse is analyzed in the consideration of exercising power in not offensive ways. It can be regarded as a method in political studies that concern with discourse roles in maintaining or reproducing an imbalanced power relations among social groups (Donoghue, 2018). This imbalances power relationship between Polri and the suspected forbidden party's sympathizers is carried out by the mental behavior showed by Polri toward the minor group. Media has played important role here in reconstructing common sense about the power delivering, therefore the action can be accepted by people. The concepts of position war reflected in the spontaneous linguistic patterns represent the relationship between discourse and the social relations as the context. Through this way, CDA can be proposed as an analytical tool for the matter of social critique and also human emancipation (Wodak \& Meyer, 2009). While the other researcher conducted a study by using the three-dimensional critical discourse analysis which consists of micro, mezzo, and macro-structural analysis to reveal the practice of rebellion (Putra and Triyono, 2018: 116-120), transitivity system proposed by Halliday was able to be utilized to analyze data in more details in which the linguistic tools were used to deliver the actor's idea or implicit intention behind the using of words in the action of dominating the minor party.

\subsection{Situational Context in the Media Coverage}

For analyzing texts in a media, the context of situations should be put into consideration. This is as conveyed by Song that critical discourse analysis attempts to unveil how power and ideology can be embodied in the discourse which has been pervaded by ideology, including both discourse structure and its content which was influenced by the context. Considering context is very essential in discourse analysis. Discourse elaborates and represents the context, and context plays a role for interpreting the utterances meaning in the discourse. In this case, situational context refers to the time, place, and environment in which the discourse takes place, including the participants relationship that determine the discourse content (Song, 2010). In the interaction point of view between journalists and readers, the journalist in this online news conducted the news activities on the topic of police actions in preventing the spread of prohibited party symbols. In this online news, the journalist constructed Badrodin Haiti as the actor who carried out the acts of discourse in which he is part of his institution, Indonesian national police under the auspices of the Indonesian government. In other words, the practice exercised by Haiti while instructing his subordinates in Polri to prevent the prohibited party's nuanced movements is an embodiment of the government's ideology as well as showing prohibited party as a form of group or organization that is prohibited from being in Indonesia. From this point of view, this study provides more discoveries than have been discovered by the Tewarat and Triyono (2019) since it is not only found out the matter of word choice used for delivering the speaker's idea through the speech text, but also about the situational context that co-frame the content of discourse. 


\subsection{The Act of Indonesian Nasional Police Chief, the Police General Badrodin Haiti in the Online News}

The results of data analysis in the form of Haiti's speech as the sayer show the acts of domination over the suspected prohibited party's sympathizers verbally. Haiti conducted a variety of speech act discourse in the form of assertive and directive. The following data are the examples of Haiti's utterances which were stated in the online news.

Table 7 The speech of Badrodin Haiti in the online news as the Indonesian national police chief regarding the phenomenon of a prohibited party awakening in Indonesia (Rimadi, 2016)

\begin{tabular}{|ll|}
\hline No. & \\
\hline 1. & $\begin{array}{l}\text { Sekarang banyak kasus ada jual merchandise seperti itu . } \\
\text { (Now there are many cases of selling merchandise like that) }\end{array}$ \\
\hline 2. & $\begin{array}{l}\text { Sudah disampaikan TAP MPRS Nomor 25 Tahun } 1966 \text { masih berlaku sampai. } \\
\text { (It has been said that TAP MPRS No. } 25 \text { of } 1966 \text { still applies until nowadays.) }\end{array}$ \\
\hline
\end{tabular}

Example (1) in Table 7 is an assertive speech act that shows the spread of prohibited party symbols is indeed a reality as the case of buying and selling merchandise items that feature the image of a hammer and sickle had been successfully revealed by the police as the evidence. Example (2) is an assertive utterance which has an implicit meaning. In his speech, Haiti asked all Indonesian people to obey the laws and regulations set by the Indonesian government regarding the prohibition of forming prohibited party's ideology group in Indonesia. In this statement (2), there is a disguised intention held by Haiti in the effort of forming Indonesian people "common sense" for doing something which they convey through verbal instructions. The quotation of a certain law cited by Haiti also becomes a form of a request for justice about the police actions exercised against the prohibited party including the sympathizers indeed deserving of being banned based on positive laws in Indonesia. Therefore, it is not only an implicit connotation that could deliver power behind the words in revealing the identity of a social leader which was found by Sahmeni and Afifah (2019: 42). The use of a certain speech act mentioned before can also represent the use of power carried out by the party who has more power and influence in dominating the other powerless groups. Furthermore, the explanation about TAP MPRS Number 25 of 1966 stated by Haiti made it clear about the existence of social practices carried out by the government which was represented by Polri and TNI towards a certain group that opposed the positive laws in Indonesia.

\subsection{The Use of Passive Sentences and Nominalization}

The analysis of syntactic and proposition structure was conducted by distinguishing passive sentence forms from the active voices used in the online news. Haiti described the opponents of his group by using nomination "the spread" in the existential process through the words "... spreading ...". In this case, Haiti gave space to the reading community to interpret itself about the act of spreading the prohibited party's ideology. It is about the real actor behind the activity while describing his superior party, the Indonesia government. Furthermore, Haiti used passivity as in the statement "..., it was clearly ordered by the law officials relating to the enforcement of this law ... " and also in the statement "...is instructed by the relevant law enforcement agencies...". These two statements were delivered in passive form without telling the subject who did the action. In other words, the real agent who carried out the action was disguised by the sayer. The online news site conveyed this 
information without changing the structure which indicates its attempt to deliver the real form of information regarding the legal law's enforcement conducted by Indonesian Nasional Police towards the parties that is prohibited from being in Indonesia

In this case, the word "ordered" implies that in taking action against the distribution of prohibited party attributes, the polices did so based on orders from a certain party who has power over their institution, in this case, it is Indonesian government so that Haiti used the term "ordered" which also shows Haiti on the same side with the government as the ruling group. This statement clearly illustrates the efforts of the more powerful parties above Polri and TNI that acted as the real actors in guarding the face (image) or avoiding face threats from the public's view of the actions taken by Polri and TNI in dealing with the prohibited party's spread movement. Thus, the honor and reputation of the government would be still maintained behind the names of the TNI and Polri.

It can be seen that there is a power relation issue negotiated in the discourse owned by the powerful group by using language which not only reflects social relations between the two parties, but is a part of them that reproduces them (Fairclough \& Wodak, 1997). Through this view, the opaqueness of social action is regarded as an effort to change socio-political practices existed before, that is in the case forbidden ideology spread. This result goes along with what was conveyed by Anggraini that there is various way in delivering message through language unit, especially for convincing public as the persuasive strategy in order to maintain the certain concept (Anggraini, 2018).

\subsection{Covering the Police Actions towards the Suspected Prohibited Party Sympathizers' Movement as a Social Practice}

The online news site liputan6.com also repeatedly used passive sentences in its reporting to reveal the actions taken by the police on the matters of relating to the prohibited party's ideology which can be seen in these following sentences: (1) "In fact, the party whose embryo (Indische Sociaal Democratische Vereeniging) was founded by Henk Sneevliet on May 9, 1914 had long been disbanded and banned in Indonesia, precisely on March $12^{\text {th }}$, 1966" and (2) "The seller was also escorted to the police station for being asked some information". Sentence (1) emphasizes that prohibited party had been dissolved and banned, while sentence (2) emphasizes that the sellers as the suspected people who were responsible for spreading prohibited party's ideology would be dealt by the police according to the laws applied in Indonesia about the acts which are prohibited to be exercised include selling particular attributes that lead to the prohibited party's ideology. Thus, it also hegemonized the public through the dissemination of information by giving certain emphasis in the news regarding the existence of awaiting punishment if there are Indonesian people who have the intention to commit acts related to prohibited party's activities in the unitary territory of the Indonesian Republic.

Furthermore, this online news provided repetition for the utterances stated by Attorney General M. Prasetyo which were delivered in passive form both for the direct speech (3)" " ... that ideology must be prevented ... ", said Prasetyo", and the indirect speech (4) "Attorney General M. Prasetyo also said, the spread of symbols that lead to prohibited party's ideology through t-shirts and attributes must be immediately prevented". Both sentences emphasize the behavior that led to prohibited party's ideology as a central point that had to be considered by the reader compared to other sentence parts. Indirectly, the readers were 
led in their subconscious about the importance of this phenomenon that the act of selling attributes lead to prohibited party's ideology is not justified and it should be "prevented". This is proved by the practice of detention conducted by Polri according to the predetermined regulations in Indonesia.

Based on the results of this study analysis, it can be seen that the laws and regulations applied in Indonesia have an important role as a hegemony tool that is very potential to lead people and make changes in the community's living system. These laws and regulations eventually become the provisions that must be obeyed by every member of society, and it also becomes their life guideline in the country. In this case, the online news site also indirectly helps the social practice exercised by the government in the dissemination of ideology which should be followed by all Indonesian citizens, because in the practice, hegemonizing is not necessarily should be carried out only by the acts of violence but there is a necessity to be supported by means that are able to attract a form of agreement from the dominated community. In this case, critical discourse analysis allows the researchers to know the way and the reason of news content is presented. The subjectivity of journalists can be examined from the perspective of journalists in portraying the reality of cases or events intentionally through the news. Putra and Triyono states that reality of facts appears differently according to the understanding and characteristics of each journalist. They even add that facts and realities delivered in the news should be clean or impartial in a certain party, but in the mass media, it becomes usual to discover another fact or interpretation from the results of a text construction analysis that leads to several multiple meanings (Putra \& Triyono, 2018).

Besides representing the actions of Polri and TNI against the suspected prohibited party sympathizers in Indonesian, this online news also carries out other social acts. It is building assumptions on the social values applied in society. This is reflected in the online news that requires mutual knowledge to produce coherences in the news telling. This finding shares the similar analysis result conducted by Asad et al. that linguistic choices in text are more in supportive towards ruling political interests. This online news can be regarded carrying the hidden intention related to the ideology that was embedded as for establishing asymmetrical power relations. Every single text contains its notions of power, hierarchy, sociological and ideological variables. They are related to the interpretation and explanation of the text (Asad et al., 2019). The social values conveyed by the online news is a common sense that the only ideology adopted by all Indonesian people is the same ideology shared by the government, not the ideology of other groups; and that the ideology of prohibited parties is a bad threat for all Indonesian people because it endangers the national security and the sovereignty of the Unitary State of the Indonesian Republic which has the only one fundamental philosophy, it is Pancasila, so that the prohibited party's existence is absolutely prohibited in this country. In addition, the movement of this group should be dealt with firmly based on the authentic laws and regulations in Indonesia.

\section{Conclusion}

By applying transitivity system combined with the critical discourse analysis in the perspective of Norman Fairclough, it can be found that there is a social practice carried out by the online news site as the media of information for the public in covering the police's actions in carrying out their duties and responsibilities to the government in terms of 
enforcing laws and regulations in Indonesia towards the spread of prohibited party's ideology that is considered to be a form of threat to the country so that a particular preventive legal actions were needed to be taken according to the positive laws that have been established in Indonesia. The readers were also hegemonized not to follow that other ideology besides Pancasila. The online news as one of the forms of discourse can be used to represent the actions of the Indonesian Nasional Police. Through this way, the online media can shape and disseminate public opinion or the common sense of Indonesian people about the latent danger of the prohibited party in Indonesia and to perpetuate the only one ideology held up by the government in order to create the situation of national stability which can be conducive to the Indonesian government system based on the principles of Pancasila and the 1945 Constitution.

\section{References}

Adjei, S. B. (2013). Discourse analysis: Examining language use in context. The Qualitative Report, 18(25), 1.

Anggraini, N. (2018). Transitivity process and ideological construction of Donald Trump's speeches. UIN Sunan Ampel Surabaya.

Asad, S., Noor, S. N. F. B. M., \& Jaes, L. Bin. (2019). Transitivity Analysis of Election Coverage in Online Newspapers of Malaysia \& Pakistan: A Study with Critical Discourse Analysis \& Systematic Functional Linguistics' Perspective. Amazonia Investiga, 8(21), 168-176.

Bednarek, M., \& Caple, H. (2012). 'Value added': Language, image and news values. Discourse, Context \& Media, 1(2-3), 103-113.

Carey, J. W. (1965). The communications revolution and the professional communicator. The Sociological Review, 13(1_suppl), 23-38. https://doi.org/https://doi.org/10.1111\%2Fj.1467-954X.1965.tbo3107.x

Cunanan, B. T. (2019). Transitivity, paradigmatic choices, and thought presentation: A stylistic analysis of Joyce's Eveline. Indonesian Journal of Applied Linguistics, 9(1), 1426. https://doi.org/10.17509/ijal.vgi1.13993

Donoghue, M. (2018). Beyond hegemony: Elaborating on the use of Gramscian concepts in Critical Discourse Analysis for Political Studies. Political Studies, 66(2), 392-408.

Eriyanto, A. W. (2001). Pengantar Analisis Teks Media. In Yogyakarta: LKiS.

Fairclough, N. (1992). Discourse and social change (Vol. 10). Polity press Cambridge.

Fairclough, N. (2000). Language and Power New York: Longman.

Fairclough, N. (2003). Analysing discourse: Textual analysis for social research. Psychology Press.

Fairclough, N., \& Wodak, R. (1997). Critical discourse analysis. Discourse Studies: A Multidisciplinary Introduction, 2(357-378).

Gramsci, A., \& Hoare, Q. (1971). Selections from the prison notebooks. Lawrence and Wishart London.

Gurevitch, M., \& Blumler, J. G. (1990). Comparative research: The extending frontier. New Directions in Political Communication: A Resource Book, 305-325.

Halliday, M. A. K., \& Matthiessen, C. (1985). An introduction to functional linguistics. London: Edward Arnold, 94. 
Halliday, M., Matthiessen, C. M. I. M., \& Matthiessen, C. (2014). An introduction to functional grammar. Routledge.

Mardikantoro, H. B. (2014). Analisis wacana kritis pada tajuk (anti) korupsi di surat kabar berbahasa Indonesia. LITERA, 13(2).

Miles, M. B., \& Huberman, A. M. (1984). Drawing valid meaning from qualitative data: Toward a shared craft. Educational Researcher, 13(5), 20-30.

Muhammad Rayhan Bustam, S. S. (2011). Analyzing clause by Halliday's transitivity system. FAKULTAS SASTRA, 1.

Mustika, P. M., \& Mardikantoro, H. B. (2018). Textual Analysis of Corruption News Text on Trans TV and Global TV Media: Critical Discourse Analysis by Norman Fairclough. Seloka: Jurnal Pendidikan Bahasa Dan Sastra Indonesia, 7(2), 173-184.

Orpin, D. (2005). Corpus linguistics and critical discourse analysis: Examining the ideology of sleaze. International Journal of Corpus Linguistics, 10(1), 37-61.

Pradnyadari, P. A., Aryawibawa, I. N., \& Rahayuni, N. S. (2018). Transitivity of English Verbs in Short Story "Pinnochio." Jurnal Humanis, Fakultas Ilmu Budaya Unud, 22(3), 633-640. https://doi.org/10.24843/JH.2018.v22.io3.p10

Prayitno, H. J., Ngalim, A., Sutopo, A., Rohmadi, M., \& Yuniawan, T. (2018). Power, Orientation, and Strategy of Positive Politeness Used by Children at The Age of Elementary School with Javanese Cultural background. Jurnal Humanus, 17(2), 164173. https://doi.org/10.24036/humanus.v17i2.101371

Putra, H. P., \& Triyono, S. (2018). Critical Discourse Analysis on Kompas. com News:'Gerakan\# 2019GantiPresiden'. LEKSEMA: Jurnal Bahasa Dan Sastra, 3(2), 113121.

Rimadi, L. (2016, May 11). Polri Gandeng TNI Cegah Penyebaran Simbol Komunis. https://www.liputan6.com/news/read/2503854/polri-gandeng-tni-cegah-penyebaransimbol-komunis

Rinaldi, R. (2017). Rhetoric dan figure of speech Minangkabau locality in tonil script Sabai Nan Aluih by Sutan Sati. Humanus, 16(2), 117-129. https://doi.org/10.24036/humanus.v16i2.7627

Sahmeni, E., \& Afifah, N. (2019). Using Critical Discourse Analysis (CDA) in Media Discourse Studies: Unmask the Mass Media. REiLA: Journal of Research and Innovation in Language, 1(2), 39-55.

Shi, W., \& Fan, M. (2019). Critical Discourse Analysis of News Texts from Transitivity Perspective.

Song, L. (2010). The role of context in discourse analysis. Journal of Language Teaching and Research, 1(6), 876.

Sudaryanto. (2015). Metode dan Aneka Teknik Analisis Bahasa: Pengantar Penelitian Wahana Kebudayaan Secara Linguistik. Duta Wacana University Press.

Tewarat, S. H., \& Triyono, S. (2019). Analyzing the President Joko Widodo's International Speech: A Study on Critical Linguistics. IJELTAL (Indonesian Journal of English Language Teaching and Applied Linguistics), 3(2), 231-247.

Wahyudin, A. Y. (2019). An Analysis of Process Type Used in News Item. Teknosastik, 14(1), $1-8$.

Watson, M. (2017). Placing power in practice theory. In The nexus of practices: Connections, constellations, practitioners. Routledge Abingdon.

Wodak, R. (2006). Mediation between discourse and society: Assessing cognitive 

approaches in CDA. Discourse Studies, 8(1), 179-190.

Wodak, R., \& Meyer, M. (2009). Critical discourse analysis: History, agenda, theory and methodology. Methods of Critical Discourse Analysis, 2, 1-33.

Yoce, A. D. (2009). Analisis Wacana Kritis. Bandung: CV YRAMA WIDYA. 